Revista Brasileira de Cartografia

ISSN 1808-0936 | https://doi.org/10.14393/revbrascartogr

Sociedade Brasileira de Cartografia, Geodésia, Fotogrametria e Sensoriamento Remoto

\title{
Subpixel Analysis of MODIS Imagery Time Series using Transfer Learning and Relative Calibration
}

\author{
Análise Subpixel de Série Temporal de Imagens MODIS usando Aprendizado por \\ Transferência e Calibração Relativa
}

Noeli Aline Particcelli Moreira ${ }^{1}$, Mariane Souza Reis ${ }^{2}$, Thales Sehn Körting ${ }^{3}$, Luciano Vieira Dutra ${ }^{4}$, Emiliano Ferreira Castejon ${ }^{5}$ and Egidio Arai ${ }^{6}$

1 National Institute for Space Research. DIOTG. São José dos Campos - SP - Brazil. noeli.aline@ inpe.br ORCID: https://orcid.org/0000-0002-5308-8080

2 National Institute for Space Research. PPGCST. São José dos Campos - SP - Brazil. mariane.reis@inpe.br ORCID: https://orcid.org/0000-0001-9356-7652

3 National Institute for Space Research. DIOTG. São José dos Campos - SP - Brazil. thales.korting@ inpe.br ORCID: https://orcid.org/0000-0002-0876-0501

4 National Institute for Space Research. DIOTG. São José dos Campos - SP - Brazil. luciano.dutra@inpe.br

ORCID: https://orcid.org/0000-0002-7757-039X

5 National Institute for Space Research. DIOTG. São José dos Campos - SP - Brazil. emiliano.castejon@ inpe.br

ORCID: https://orcid.org/0000-0002-4148-2830

6 National Institute for Space Research. DIOTG. São José dos Campos - SP - Brazil. egidio.arai@inpe.br

ORCID: https://orcid.org/0000-0003-1994-5277

\begin{abstract}
Transfer learning reuses a pre-trained model on a new related problem, which can be useful for monitoring large areas such as the Amazon biome. A given object must have similar spectral characteristics in the data used for this type of analysis, which can be achieved using relative calibration techniques. In this article, we present a relative calibration process in multitemporal images and evaluate its impacts on a subpixel classification process. MODIS images from the Amazon region, collected between 2013 and 2017, were relatively calibrated using a 2012 image as reference and classified by transfer learning. Classifications of calibrated and uncalibrated images were compared with data from the PRODES project, focusing on forest areas. A great variation was observed in the spectral responses of the forest class, even in images of proximate dates and from the same sensor. These variations significantly impacted the land cover classifications in the subpixel, with cases of agreement between the uncalibrated data maps and PRODES of $0 \%$. For calibrated data, the agreement values were greater than $70 \%$. The results indicate that the method used, although quite simple, is adequate and necessary for the subpixel classification of MODIS images by transfer learning.
\end{abstract}

Keywords: Relative Calibration. Image Time-series. Samples Extension. Subpixel Analysis. Land Cover classification.

Resumo: O aprendizado por transferência reutiliza um modelo pré-treinado em um novo problema relacionado, o que pode ser útil para monitorar áreas extensas como o bioma Amazônia. Para tal, é importante que um determinado objeto possua características espectrais semelhantes nos dados utilizados, sendo que variações nesses valores podem ser minimizadas com técnicas de calibração relativa. Neste artigo, apresenta-se um processo de calibração relativa em imagens multitemporais e como essa calibração impacta processos de classificação subpixel. Imagens MODIS da região Amazônica, coletadas entre 2013 e 2017, foram relativamente calibradas usando uma imagem de 2012 como referência e classificadas por apredizado por transferência. As classificações de imagens calibradas e não calibradas foram comparadas com dados do projeto PRODES, com foco nas áreas de florestas. Observou-se grande variação nas respostas espectrais da classe floresta, mesmo em imagens de datas próximas e do mesmo sensor. Essas variações impactaram significativamente nas classificações de cobertura da terra no subpixel, com casos de concordância entre os mapas de dados não calibrados e PRODES de 0\%. Para os dados calibrados, os valores de concordância foram superiores a 70\%. Os resultados indicam que o método utilizado, embora bastante simples, seja adequado e necessário para a classificação subpixel de imagens MODIS por transferência de aprendizado.

Palavras-chave: Calibração Relativa. Série Temporal de Imagens. Extensão de Amostras. Análises Subpixel. Classificação da Cobertura da Terra. 


\section{INTRODUCTION}

Land cover changes in Amazon can impact important ecosystem elements such as the carbon and hydrological cycles, as well as regional and global climatic balance (FOLEY et al., 2017). Because Amazon's importance to central aspects of the Earth System functioning and human sustenance (CHHABRA et al., 2006), mapping and monitoring land cover changes in this region is crucial to understand and mitigate the impacts of human actions and to better plan public policies.

Orbital remote sensing images are one of the main data used for land cover monitoring in Amazon, as evidenced by many projects dedicated to this task (DINIZ et al., 2015; ALMEIDA et al., 2016; INPE, 2019). Many of these projects have been conducted using medium-resolution optical remote sensing data, which can be unavailable due to atmospheric conditions and cloud cover during certain times of the year. One solution to this problem is to select cloud-free images sensed by high-temporal resolution sensors, such as the Moderate Resolution Imaging Spectroradiometer (MODIS), onboard the AQUA and TERRA satellites.

MODIS data are collected with daily revisits and provided at no cost (JUSTICE et al., 2002), which enhances the chances of finding suitable images to use on a specific date. However, MODIS data present coarse spatial resolution $(231 \mathrm{~m})$ that led to the mixture of the spectral information of target land cover classes in the same pixel, resulting in mixed pixels (FOODY, 2004). Since a single land cover class cannot be appropriately assigned to a mixed pixel, the monitoring and adequate detection of changes are hindered in this type of data. The typical solution for the mixed pixel problem is performing a subpixel analysis (ZHANG, 1998; FOODY, 2004).

Subpixel analyses are those in which information about the land cover is extracted at a scale finer than the pixel resolution. Many approaches for subpixel analysis have been proposed in the literature, and subpixel scale information is usually represented as some measure of the proportion of each class in the pixel (FOODY, 2004). Following this principle, it is possible to define different class typologies composed by different proportions of land cover classes, usually identified with higher spatial resolution images, and use these typologies as the actual classes to be analyzed in the images with lower spatial resolution. Collecting labeled samples (necessary for supervised classification, for example) of this type of class is only possible with extensive field data collection or the availability of higher spatial-resolution data, which generally is not the case for extensive time-series analysis. This detailed data usually is only available for a few dates, from which the spectral information can, potentially, be collected and used to classify images from different dates. This process is known as signature extension, spectral extensibility, generalization of training samples (WOODCOCK et. al, 2001), or transfer learning (DEMIR; BOVOLO; BRUZZONE, 2012). The effectiveness of this method is highly dependent on the radiometric consistency of images (OLTHOF; BUTSON; FRASER, 2005). However, the radiometric consistency between separate images from any given optical sensor is difficult to maintain, due to different atmospheric conditions, variations in the solar illumination, variations within the sensor in time (DU; TEILLET; JOSEPH, 2002), and phenological changes. These differences may be minimized in a preprocessing step known as radiometric calibration (YUAN; ELVIDGE, 1996; YANG; LO, 1996).

Radiometric calibration techniques are usually divided into two main categories: absolute and relative. In absolute radiometric calibration, measures related to physical characteristics of targets in Earth surface, usually expressed as radiance or reflectance values, are calculated using models based on sensor calibration coefficients, atmospheric/imaging conditions, and/or ground truth data (DU; TEILLET; JOSEPH, 2002; HU; LIU; JIAO, 2011). This type of calibration, although indispensable for deriving physical properties of land objects, does not, generally, permit the use of transfer learning to classify imagery for dates where one does not have training data, mainly because of phenological changes between dates. Transfer learning is a reuse of a pre-trained model in a new related problem; in this case, aiming to classify an image of different dates, but using the same sensor and classes. The process of transferring classification models estimated in one date to another one requires that the class patterns occupy the same region in the feature space. Phenological changes alter the feature space, precluding the classification models' re-use. Relative radiometric corrections, however, can be used to normalize the feature space. In these cases, images are normalized to a reference image, based on a given set of statistical parameters. These parameters may vary depending on the used 
method, being the most common ones the adjustment of average and standard deviation values, histogram matching, and application of gain and offset values by linear regression (DU; TEILLET; JOSEPH, 2002; HU; LIU; JIAO, 2011; PONZONI; SHIMABUKURO, 2007).

The relative calibration of remote sensing data is an established practice and has been used in many types of research (HALL et al., 1991; CHANDER; MEYER; HELDER, 2004; PAHLEVAN; SCHOTT, 2012). The impacts of using these techniques for transfer learning, however, have not been fully analyzed, mainly because traditional softwares do not permit the training of the classifier independently of the image to be classified. In this sense, it is also not usual to use multi-resolution imagery to define different typologies to be used to classify mixed pixels in images of lower spatial resolution. Given this scenario, the present study aims to evaluate the classifications obtained by transfer learning, after relative calibration results of a MODIS timeseries composed of six images from 2012 to 2017, covering a region within the Brazilian Amazon. A new set of tools, named Subpixel Analysis Tools (SPAT) and explained in Section 2, was used to perform the experiment. SPAT reunites important tools to enable subpixel and transfer learning analyses that were very expensive to perform previously. Therefore, the present research presents some important contributions: 1) the formalization of a methodological protocol for the subpixel classification of remote sensing image time-series using the proportion of land cover classes, instead of land cover elements, which allows for a more intuitive perception of change in classes of interest; 2) the land cover classes, class proportion, and used datasets have been adapted for a study case in Amazon, which highlights specific needs for future work in real monitoring situations; and 3) it presents a new set of tools that may facilitate the use of transfer learning and/or subpixel analysis in other remote sensing works. The study area, methods, and data used for subpixel analysis are also explained in Section 2. The results are presented and discussed in Section 3. Conclusions and suggestions for future works are drawn in Section 4. This manuscript is an extended, updated, and improved version of Moreira et al. (2019), presented in the XX Brazilian Symposium on GeoInformatics (GEOINFO 2019).

\section{MATERIALS AND METHODS}

In this study, we calibrated and classified six MODIS images collected over a region within Brazilian Amazon, described in Section 2.1, using different methods implemented in SPAT and the auxiliary data described in Sections 2.2 and 2.3. The used methodology encompassed 5 basic steps: 1) the exploratory analysis of data (Section 2.4); 2) the relative calibration of the MODIS image time-series. This step was conducted using simple linear regression models and labeled samples of pure pixels, which were collected using auxiliary higher resolution images of proximate dates (Section 2.5); 3) the determination of land cover typologies, based on the clustering analysis of the proportion of land cover classes in a higher resolution land cover map (Section 2.6); 4) the use of labeled samples of these typologies to train supervised classifiers used to classify all images of the MODIS time-series (Section 2.6); and 5) evaluation of results. The methodology used is summarized in the flowchart from Figure 1 and explained in Sections 2.4 to 2.7. 
Figure 1- Methodological flowchart.

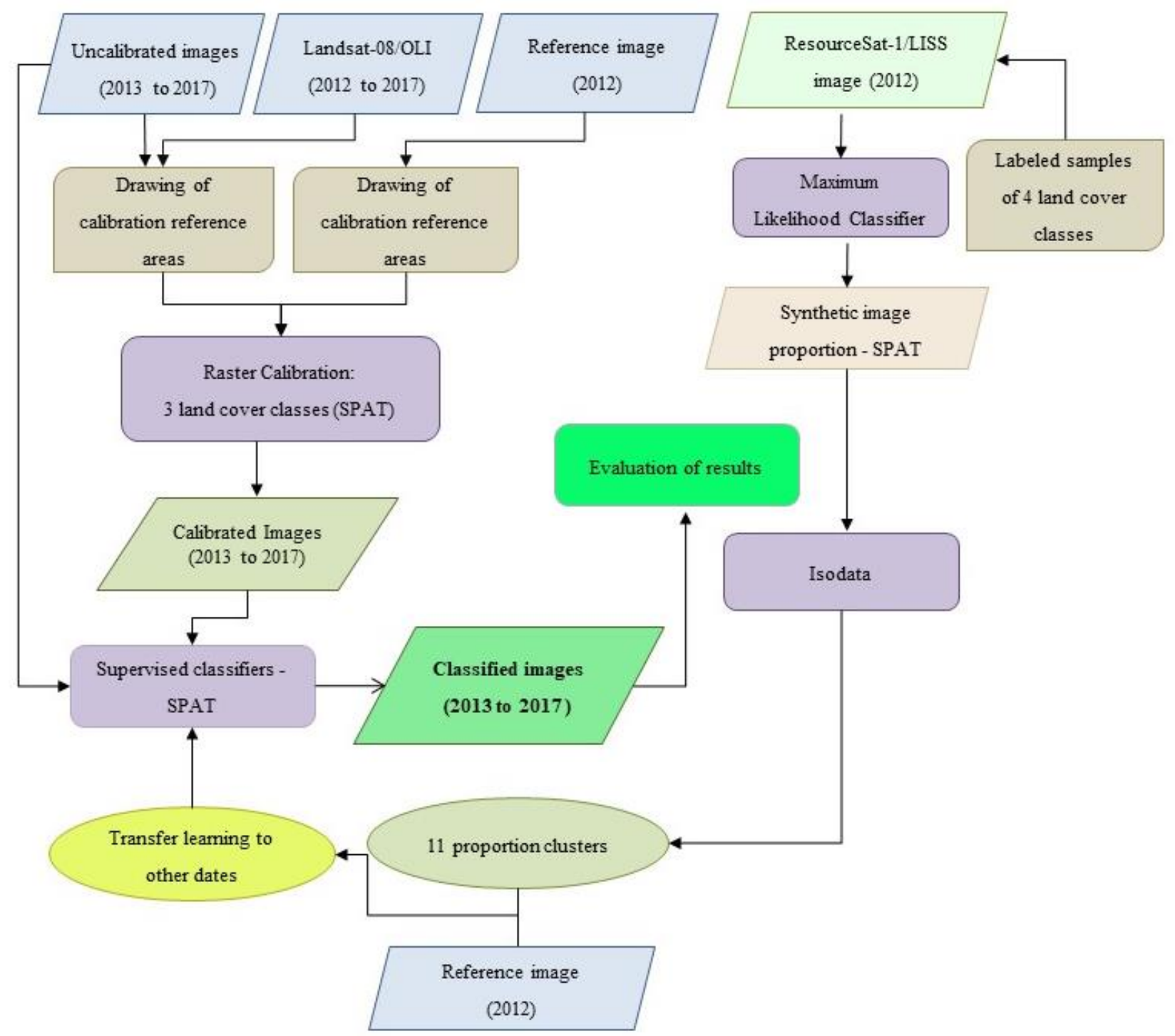

Source: The authors (2020).

\subsection{Study area}

The study area is located in the Belterra and Santarém municipalities, both in the southwest of Pará state in Brazil, as illustrated in Figure 2. This area covers a subset of the National Tapajós Forest, part of the Tapajós River, and part of the BR-163 highway. It is a highly dynamic and heterogeneous area that presents patches of secondary vegetation, pasture, and agriculture within the forest matrix, thus being adequate for the proposed analysis. In this area, we can identify four major land cover classes (REIS et al., 2018): Forest, Pasture/Agriculture, Bare Soil, and Water. 
Figure 2 - Location of the study area concerning political-administrative limits, along with a MODIS image from August 04, 2012.
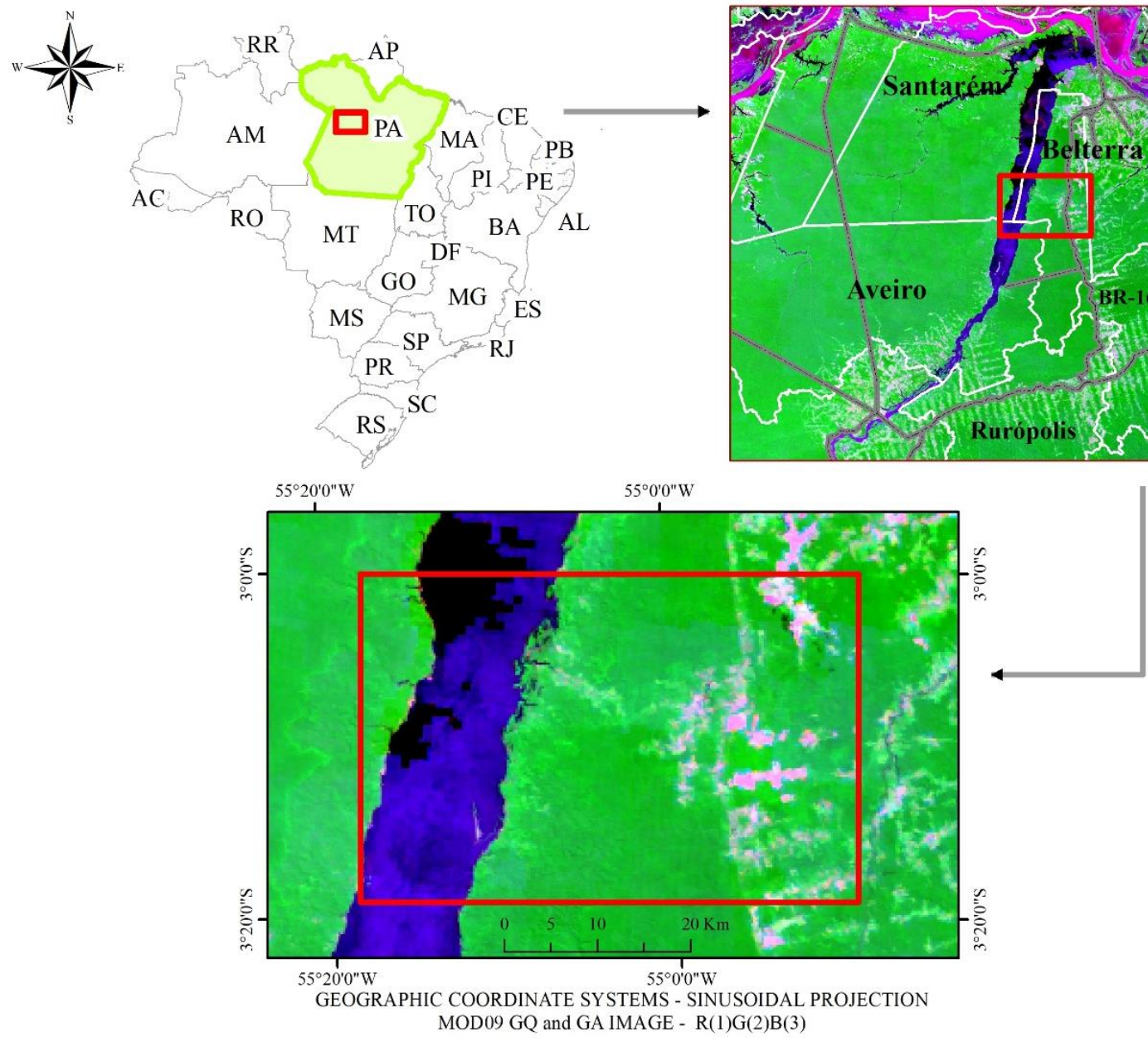

Source: The authors (2020).

\subsection{Remote sensing images and land cover data collection}

In this section, we present the remote sensing images used in this study. We calibrated one MODIS image from each year between 2013 and 2017 using another MODIS image from 2012 as reference. Additionally, five Landsat-08/Operational Land Imager (OLI) images, one ResourceSat-01/ Linear Imaging Self-Scanner (LISS) image, and two more MODIS images were also used as auxiliary data. Auxiliary MODIS images were only used to analyze the spectral behavior of an unchanged forest region on consecutive observations, as detailed in Section 2.4. OLI images were used to collect labeled samples for the relative calibration process (Section 2.5). The LISS image was classified in four land cover classes and this classification was used to determine the typologies for the subpixel analysis, as explained in Section 2.6.

The dates of the used images are presented in Chart 1 . The choice of date was made to maximize proximity among dates and to minimize cloud cover. MODIS images were acquired from the tile h12v09 in MOD09GQ (bands Red and NIR) and MOD09GA (bands Blue and MIR), with respectively $231 \mathrm{~m}$ and $462 \mathrm{~m}$ of spatial resolution, from the Land Processes Distributed Active Archive Center (LP DAAC). These bands were selected empirically, based on the good results previously obtained by the research group using different MODIS products. ResourceSat-01/LISS and Landsat-08/OLI images, respectively with $23 \mathrm{~m}$ and $30 \mathrm{~m}$ of spatial resolution, were downloaded from National Institute for Space Research (INPE) catalog. 
Chart 1 - Used images. Dates are expressed as day/month/year.

\begin{tabular}{|c|c|c|}
\hline \multirow{2}{*}{ MODIS time-series } & \multicolumn{2}{|c|}{ Auxiliary images } \\
\cline { 2 - 3 } & MODIS & Higher spatial-resolution \\
\hline $04 / 08 / 2012$ (reference) & $01 / 08 / 2012$ & ResourceSat-1/LISS: 01/08/2012 \\
\hline $04 / 08 / 2013$ & $02 / 08 / 2012$ & Landsat-08/OLI: $25 / 09 / 2013$ \\
\hline $29 / 09 / 2014$ & & Landsat-08/OLI: $30 / 10 / 2014$ \\
\hline $16 / 07 / 2015$ & & Landsat-08/OLI: $29 / 07 / 2015$ \\
\hline $30 / 06 / 2016$ & & Landsat-08/OLI: $15 / 07 / 2016$ \\
\hline $17 / 07 / 2017$ & & Landsat-08/OLI: $18 / 07 / 2017$ \\
\hline
\end{tabular}

Source: The authors (2020).

The geometric adjustment of MODIS, ResourceSat-01/LISS, and Landsat-08/OLI images was checked. Since MODIS and Landsat-08/OLI data were found to be suitably aligned, the ResourceSat-01/LISS image was registered to MODIS data using a first polynomial transformation and nearest neighbor resampling method, using ENVI version 4.7 image processing software (Exelis Visual Information Solutions, Boulder, Colorado). The images from the MOD09GA product were re-sampled to $231 \mathrm{~m}$ of pixel size and then stacked with those from MOD09GQ using ENVI version 4.7.

\subsection{SubPixel Analysis Tools - SPAT}

SPAT is a set of tools focused on different steps of subpixel analysis, developed using the open-source TerraLib library (CÂMARA et al., 2008) and available for free download. The current version, namely SPAT_0_1_12-alpha-develop (CASTEJON, 2017), is composed of five modules illustrated in Figure 3. These are:

a) Classproportions: creates a synthetic image with a given pixel size based on a classified image of higher spatial resolution. Each pixel in the generated image depicts the proportion of land cover classes in the corresponding areas in the classified images. Each class is represented in one channel;

b) Clusteranalysis: computes the cluster statistics of a classified image, i.e. the average vector and the covariance matrix used to train the classifiers based on transfer learning, depending on the selected classification method;

c) Rastercalibration: performs the relative calibration in one or more images, using another one as the reference. Samples of correspondent classes are collected over the reference image and those to be calibrated. These samples are used to calculate values of gain and offset to be applied in the images to be calibrated. Current calculation methods include normalization of average and standard deviation and simple linear regression by the least square error method;

d) Classifier: applies supervised or unsupervised classification algorithms to classify one image. Supervised classifiers are configured to use training samples collected over an independent image, which allows the use of transfer learning. Maximum Likelihood Classifier, Minimum Distance (Euclidian), K-Means and ISOData classifiers are implemented;

e) Changeanalysis: detect changes between pairs of classified images (post-classification comparison method). It is possible to define specific transitions as change and the tool provides the relative amount of changed pixels.

The parameters used in the present study are detailed in Chart 2 . 
Figure 3- Modules in SPAT.

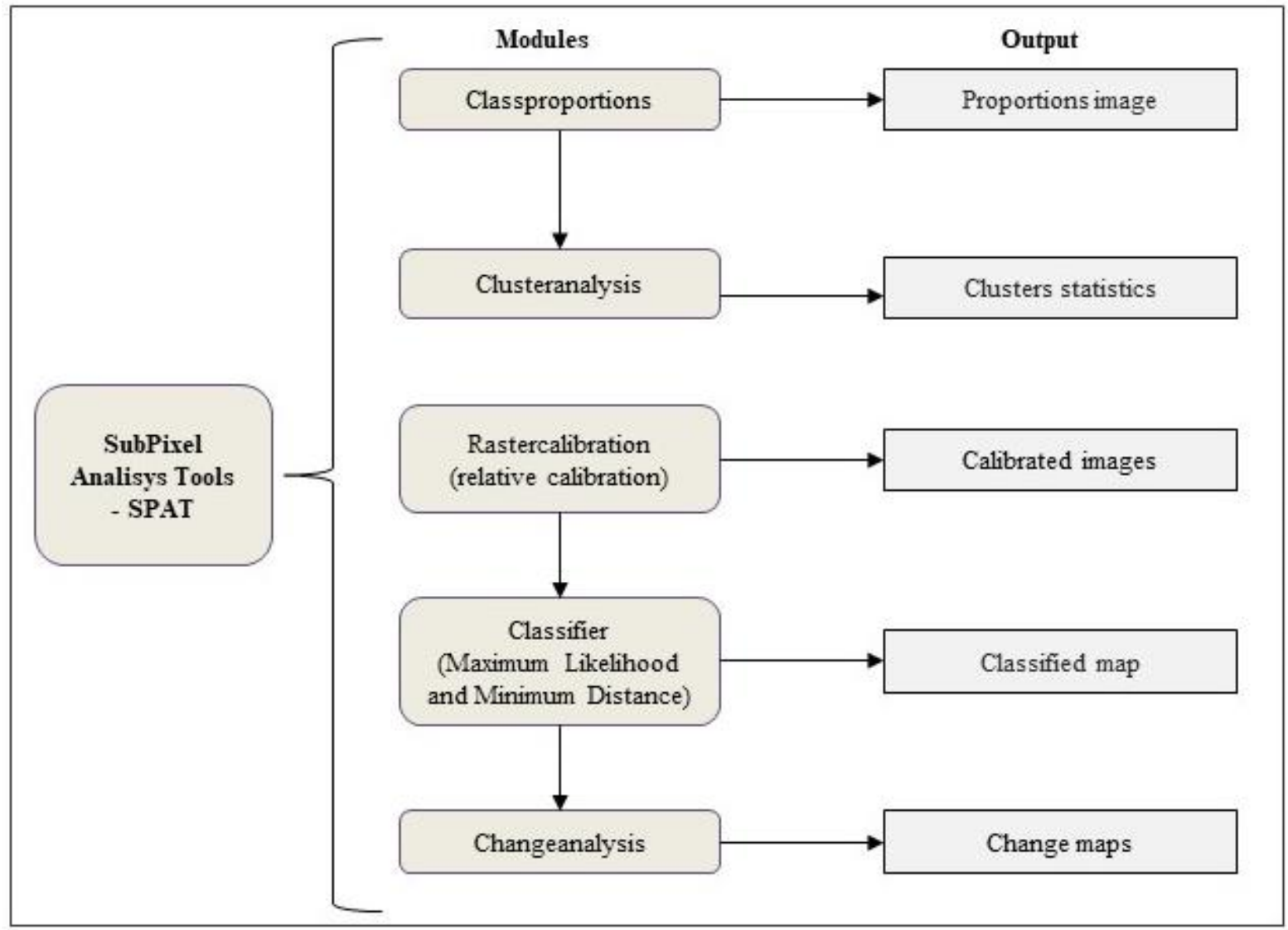

Source: The authors (2020).

Chart 2 - Input and parameters for each module in SPAT.

\begin{tabular}{|c|c|c|c|}
\hline & Input & Parameters & Input used in this research \\
\hline \multirow{3}{*}{ Classproportions } & Image of low resolution & \multirow[b]{2}{*}{ - } & MODIS image from 2012 \\
\hline & Land cover classification & & $\begin{array}{c}\text { Classification of the } \\
\text { ResourceSat-01/LISS } \\
\text { image }\end{array}$ \\
\hline & Grouping factor & Value of pixel proportion & $100 \%$ \\
\hline \multirow{2}{*}{ Cluster analysis } & Map of typical clusters & \multirow{2}{*}{ - } & Map of typical clusters \\
\hline & Reference image of low resolution & & MODIS image from 2012 \\
\hline \multirow{5}{*}{ Raster calibration } & Reference image & \multirow{4}{*}{ - } & MODIS image from 2012 \\
\hline & Uncalibrated image & & MODIS image (2013 to 2017) \\
\hline & $\begin{array}{l}\text { Labeled samples from the reference } \\
\text { image }\end{array}$ & & $\begin{array}{c}\text { Labeled samples of } 3 \text { land } \\
\text { cover classes }\end{array}$ \\
\hline & Labeled samples from uncalibrated image & & $\begin{array}{c}\text { Labeled samples of } 3 \text { land } \\
\text { cover classes }\end{array}$ \\
\hline & Calibration method & $\begin{array}{c}1 \text { - equalization of average } \\
\text { and standard deviation; } \\
\text { 2- linear regression (least } \\
\text { square method) }\end{array}$ & $\begin{array}{l}2 \text {-linear regression (least } \\
\text { square method) }\end{array}$ \\
\hline \multirow{3}{*}{ Classifier } & Image for classification & \multirow[b]{2}{*}{ - } & MODIS images (2012 to 2017) \\
\hline & Training samples & & $\begin{array}{l}\text { Clustering of } 2012 \text { land cover } \\
\text { classification }\end{array}$ \\
\hline & Method & $\begin{array}{l}\mathrm{ED}=\text { Minimum Distance and } \\
\mathrm{MV}=\text { Maximum Likelihood }\end{array}$ & ED and MV \\
\hline
\end{tabular}

Source: The authors (2020).

\subsection{Exploratory analysis of data}

As previously explained in Section 1, remote sensing images from the same sensor can present variation in signal values that are not related to changes in the land cover, even for proximate dates. A 
preliminary analysis of the MODIS images from 2012 was performed to assess this variation. We selected 576 pixels that corresponded to forested areas of no change in three images of very proximate dates (August 01, 02 , and 04). We then analyzed variations in the digital number values of each band from the uncalibrated images. The values from each band were illustrated as line graphics and analyzed in terms of values variation in time and space.

\subsection{Relative calibration}

Each one of the five MODIS images from 2013 to 2017 was radiometric calibrated using the MODIS image from 2012 as reference. For each band of each image, we calculate the average value of digital numbers for each one of the three classes 'Forest', 'Pasture/Agriculture', and 'Bare Soil', using the labeled samples of the respective years. Labeled samples of 'Water' were not used in this step because of the presence of many pixels of no value. The collection of labeled samples was done over the Landsat-08/OLI images, so the selected regions do not represent mixed classes in MODIS images, as illustrated by Figure 4.

Based on Du, Teillet and Joseph (2002), we assumed that pixels of the same classes sampled at two different times are linearly related. We calculated the average value of the pixels of each class in each band of the MODIS image of each date. From these values, we used the least square method to fit a straight line that relates the uncalibrated image band to the reference image (MODIS 2012) by a value of gain and offset, as illustrated in Figure 5. Relative calibration was performed by the application of these gain and offset values. The results of the calibration process were evaluated by comparing the average and standard deviation values from each class before and after calibration.

Figure 4 - Selection of labeled samples of 3 land cover classes.
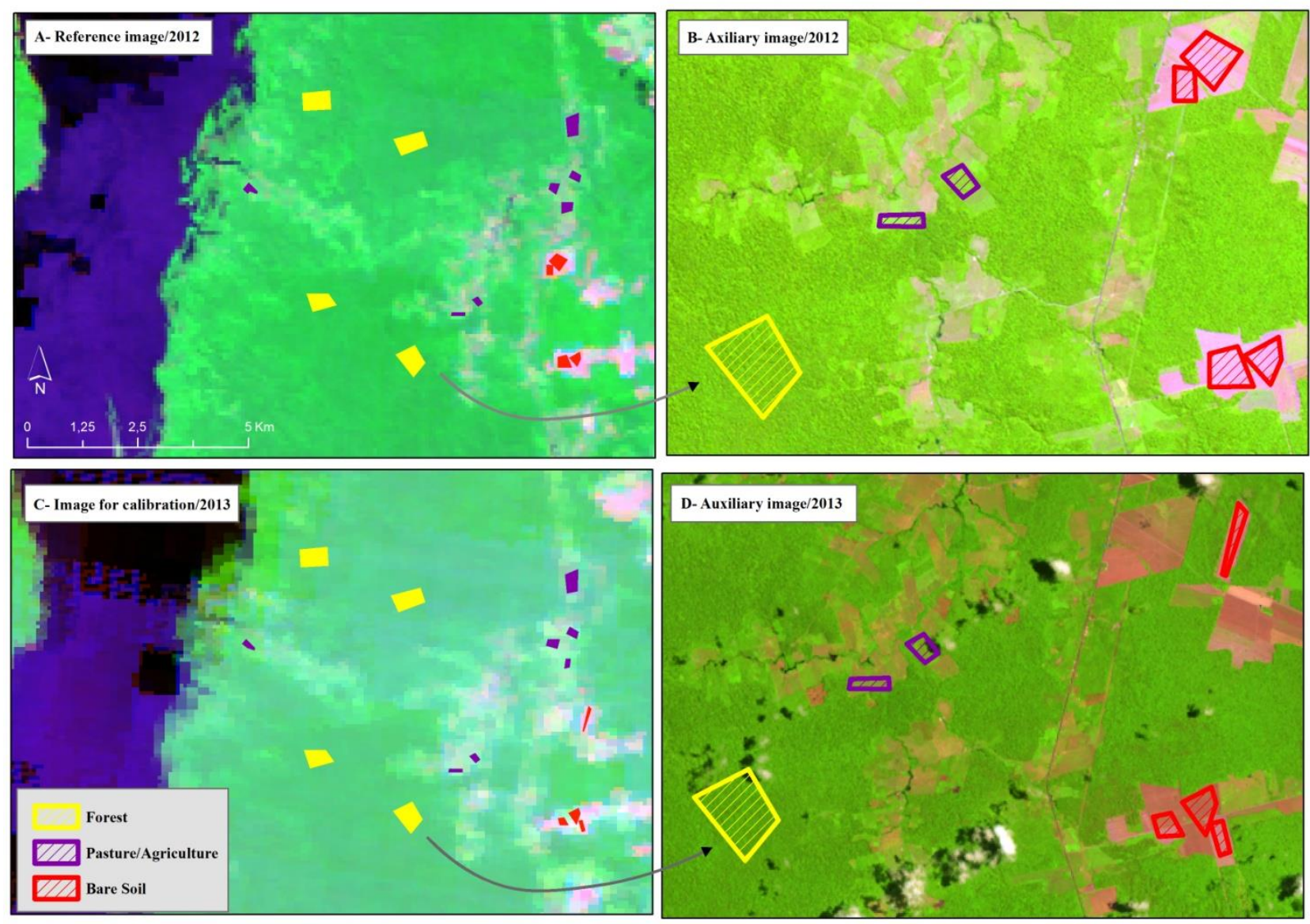

Source: The authors (2020). 
Figure 5 - Illustration of the relative calibration method used, in which $\mathrm{Y}=$ reference value, $\mathrm{x}=$ adjust image, a $=$ Gain value, $\mathrm{b}=$ Offset value, $\mu \mathrm{BS}=$ average value of Bare Soil, $\mu \mathrm{F}=$ average value of Forest, $\mu \mathrm{PA}=$ average value of Pasture/Agriculture.

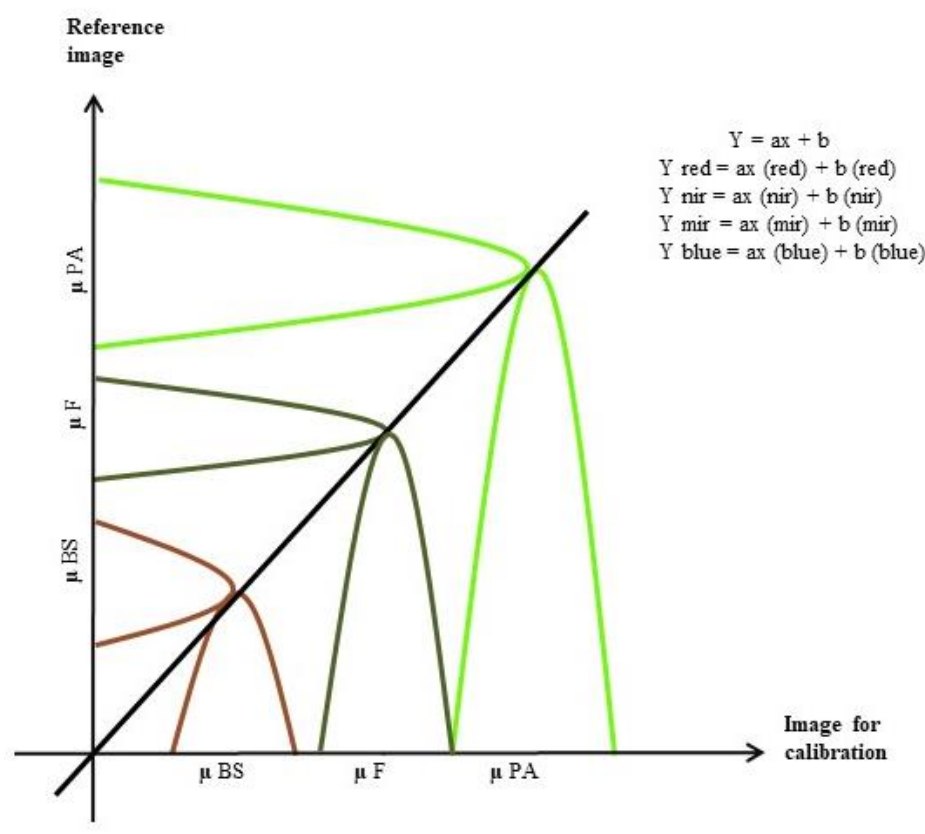

Source: The authors (2020).

\subsection{Typology definition and time-series classification}

We generated a land cover map from 2012 containing the four land cover classes, by the classification of the ResouceSat-1/LISS image. The classes 'Water', 'Forest', 'Agriculture/ Pasture', and 'Bare Soil' were classified using a Maximum Likelihood Classifier and the correspondent labeled samples. From this map, we calculated the proportion of each land cover class in the $231 \mathrm{~m}$ pixels of the 2012 MODIS image. These proportions were then grouped in 11 clusters using the Isodata algorithm and the parameters confidence level $=5 \%$ and number of iterations $=20$, following previous results presented in Moreira et al. (2018). These clusters are related to different typologies of mixed pixels and will be referred to as 'proportion clusters' in this study.

The proportion clusters were then used to train the two classifiers within Classifier (Maximum Likelihood and Minimum Euclidian Distance), later used to classify the MODIS images from 2013 to 2017. We classified both the calibrated and original images, to assess the impacts of calibration in the classification process.

\subsection{Evaluation of the results}

We analyzed the resulting proportion clusters and identified those that had a correspondent class within the data from the System for Monitoring the Brazilian Amazon Forest by Satellite, also known as PRODES. For this task, we then randomly selected 320 random points in PRODES data from 2017, since these areas can be considered as forest in all the analyzed dates, and evaluated the percentage of these samples that were classified as each one of our used typologies.

\section{RESULTS AND DISCUSSION}

\subsection{Signal variation in 2012 images of proximate dates}

The values of labeled samples of Forest class collected in the MODIS images from 2012 are illustrated 
in Figure 6. This figure shows 576 pixels in areas that did not suffer any change in land cover. As can be seen, these pixels can present distinct values in images of very proximate dates (less than three days of difference). Nonetheless, the format of the curves of each channel is similar for different dates, which indicates that the simple application of a linear transformation is capable to diminish the observed differences. Furthermore, it is possible to see that differences in the values vary depending on the observed band, further justifying the need to normalize data band by band.

Figure 6 - Variation of signal in samples from Forest class in MODIS images from 2012 represented by the ordered reading of 576 pixels
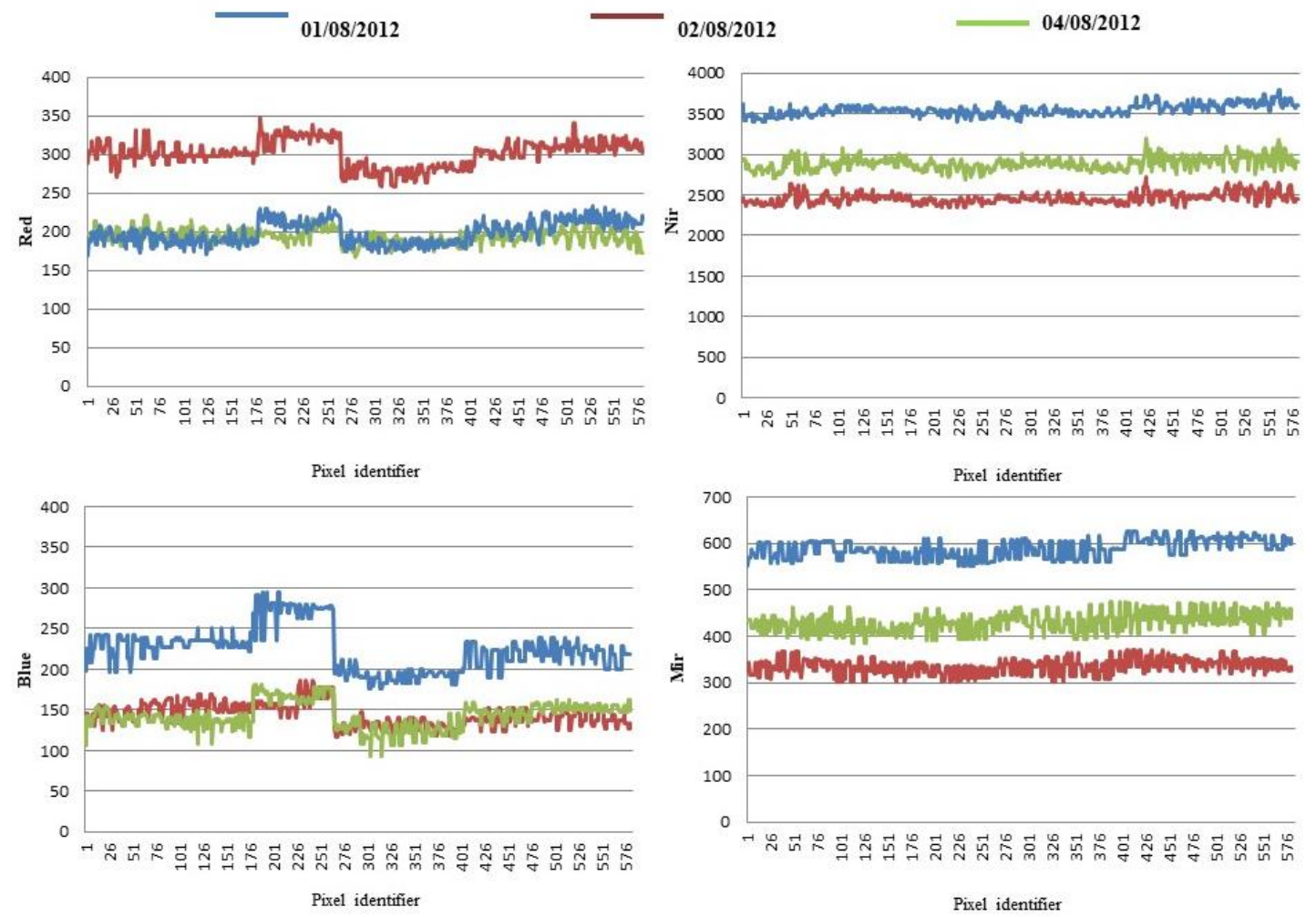

Source: The authors (2020).

\subsection{Effects of radiometric calibration on signal}

Chart 3 and Figure 7 present the average values of samples for each class before and after calibration, with the values of the reference image for comparison. Overall, the majority of values were adjusted to decrease the difference between the calibrated image and the reference. Nonetheless, there are some cases in which the difference between these values increased, such as occurred for the Red and MIR bands for the Bare Soil class in 2016 and 2017. Although this type of behavior for single classes is expected given the mathematical approach of the calibration model, analysis with more than three classes may reveal other characteristics.

As can be seen in Chart 3, there are significant differences among the average values for labeled samples of the same targets of uncalibrated and reference images. The relative calibration process was effective in decreasing these differences, which is an essential feature for the application of transfer learning. These results can be more easily observed in Figure 7, in which the average values for samples of each class, before and after calibration, are represented along with the average value of the samples of each class in the reference image. As can be seen, the most dramatic adjustment was conducted for the images of 2013 and 2014, which presented a higher variation in the average of each class. It is also worth note that the band NIR presented very varied values for each year in uncalibrated images. The calibration process was particularly effective for this band since results show much more standardized values. 
Chart 3 - Average values of labeled samples of each class in reference, calibrated, and uncalibrated images.

\begin{tabular}{|c|c|c|c|c|c|c|c|c|c|c|c|c|}
\hline & \multicolumn{4}{|c|}{ AVERAGE FOREST } & \multicolumn{4}{|c|}{$\begin{array}{c}\text { AVERAGE } \\
\text { PASTURE/AGRICULTURE }\end{array}$} & \multicolumn{4}{|c|}{ AVERAGE BARE SOIL } \\
\hline & Red & NIR & Blue & IIIR & Red & NIR & lue & MIR & Red & JIR & Blue & MIR \\
\hline & 6.83 & 77.60 & 17.80 & 33.54 & 442.57 & 3137.41 & 258.27 & 826.91 & 1540.97 & 2520.32 & 650.42 & 184.21 \\
\hline $\begin{array}{l}2013 \\
\text { uncalibrated }\end{array}$ & 32.09 & 84.98 & 199.23 & 73.38 & 493.67 & 4092.49 & 299.84 & 842.51 & 914.76 & 3872.19 & 411.57 & 141.14 \\
\hline $\begin{array}{l}2014 \\
\text { uncalibrated }\end{array}$ & 8.47 & 4527.67 & 30.28 & 36.09 & 880.47 & 4038.76 & 523.74 & 1473.38 & 2258.46 & 3770.46 & 1177.60 & 3105.40 \\
\hline librated & 054 & 25.29 & 01.02 & 51.50 & 490.58 & 4222.59 & 293.01 & 824.78 & 1325.32 & 2945.43 & 555.41 & 1937.00 \\
\hline & 6.65 & 22.51 & 158.79 & 49.56 & 387.50 & 4209.84 & 234.66 & 788.09 & 1534.33 & 2783.02 & 613.53 & 2263.30 \\
\hline $\begin{array}{l}2017 \\
\text { uncalibrated }\end{array}$ & 77.42 & 2800.79 & 121.93 & 92.30 & 351.27 & 3410.27 & 206.17 & 742.41 & 1306.24 & 2474.16 & 592.09 & 2122.01 \\
\hline $\begin{array}{l}\text { calib } \\
2013\end{array}$ & 6.76 & 2732.50 & 103.05 & 30.63 & 577.91 & 2948.24 & 343.32 & 1117.63 & 1495.71 & 2854.59 & 610.12 & 2046.40 \\
\hline $\begin{array}{l}\text { calibrated } \\
2014\end{array}$ & 73.46 & 2990.28 & 145.80 & 01.63 & 485.93 & 2819.41 & 260.87 & 870.31 & 1531.00 & 2725.64 & 649.83 & 2172.73 \\
\hline $\begin{array}{l}\text { calibrated } \\
2015\end{array}$ & 186.66 & 2743.65 & 138.64 & 456.47 & 468.07 & 3166.76 & 270.65 & 798.36 & 1535.66 & 2624.92 & 647.21 & 2189.84 \\
\hline $\begin{array}{l}\text { calibrated } \\
2016\end{array}$ & 46.55 & 2730.15 & 160.68 & 506.75 & 397.63 & 3162.16 & 242.81 & 741.87 & 1546.20 & 2643.01 & 653.00 & 2196.05 \\
\hline $\begin{array}{l}\text { calibrated } \\
2017\end{array}$ & 1.55 & 2785.75 & 157.62 & 452.10 & 425.17 & 3169.46 & 246.31 & 803.65 & 1543.65 & 2580.12 & 652.56 & 2188.92 \\
\hline
\end{tabular}

Source: The authors (2020).

Figure 7- Average values of each land cover class from MODIS data. These values are scaled by 10,000.
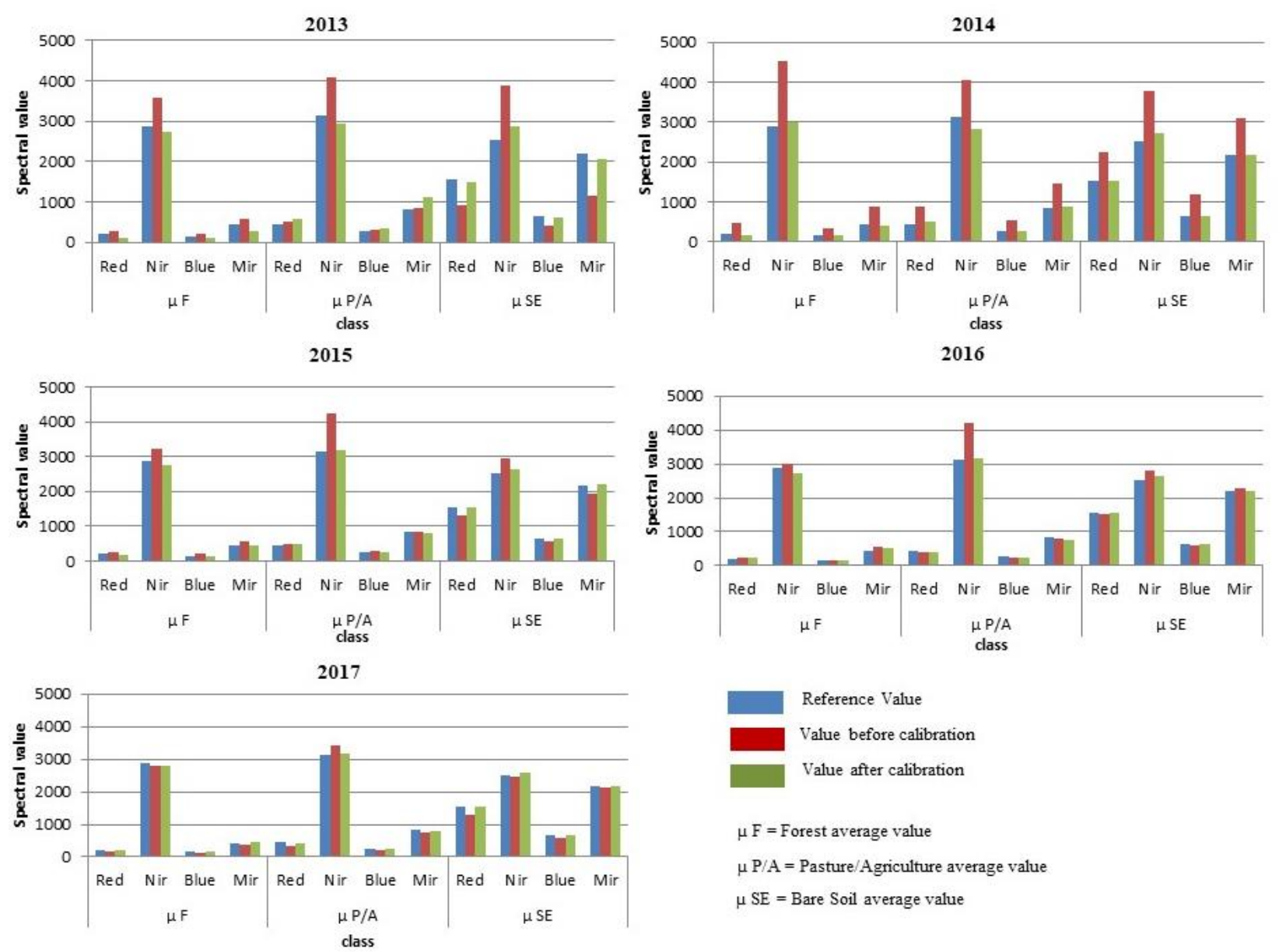

Source: The authors (2020). 


\subsection{Classification of images from 2013 to 2014}

The 11 proportion clusters obtained from the clustering of the land cover classification of 2012 were overlaid on the MODIS image from 2012 (reference) and used as labeled samples to train the classifiers. These clusters were used to train two classifiers and to classify the MODIS time-series. Given the high quantity of pixels without values (No data) in the MODIS time-series over areas of water, the proportion clustering 7 was extracted from 2012 and masked over the classifications of the remaining years. The classification results from 2013, and 2014 are presented in Figures 8 and 9, for illustration, along with the reference map from 2012.

Figure 8- MODIS classification results using the Minimum Euclidian Distance Classifier. In which $\mathrm{F}=\mathrm{Forest}$, $\mathrm{W}=$ Water, $\mathrm{PA}=$ Pasture/Agriculture, and $\mathrm{BS}=$ Bare Soil.
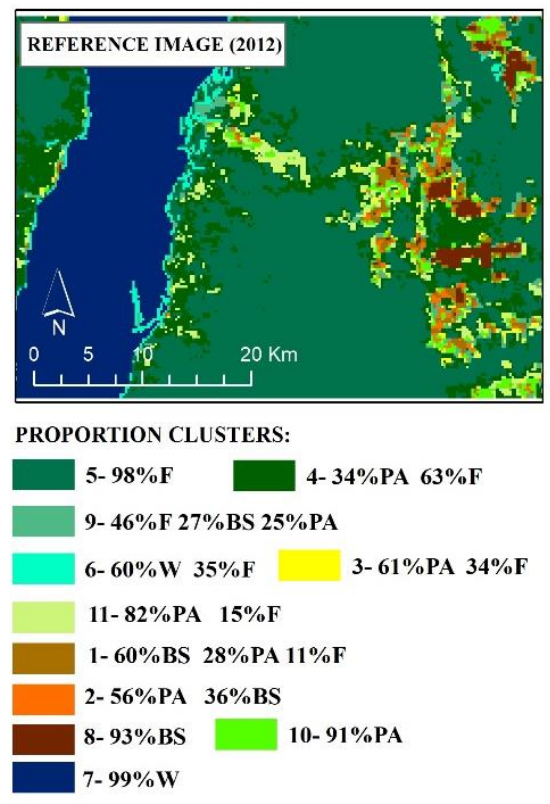
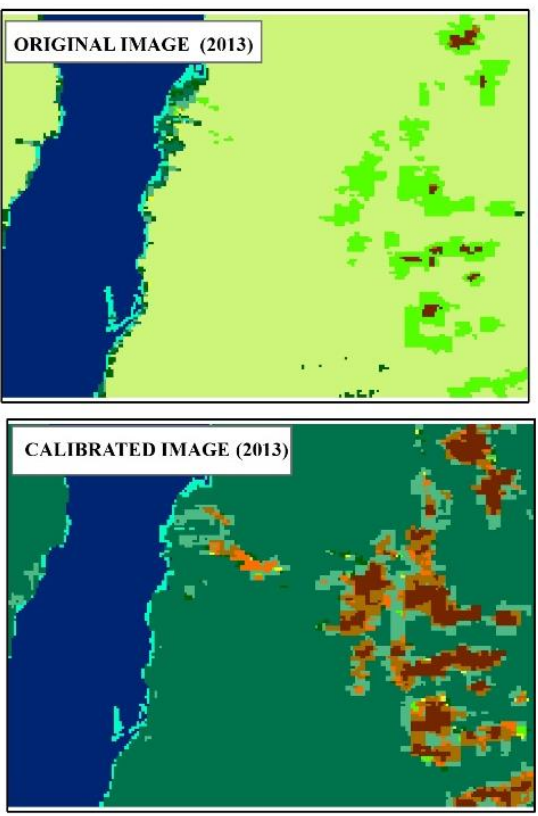

Source: The authors (2019).
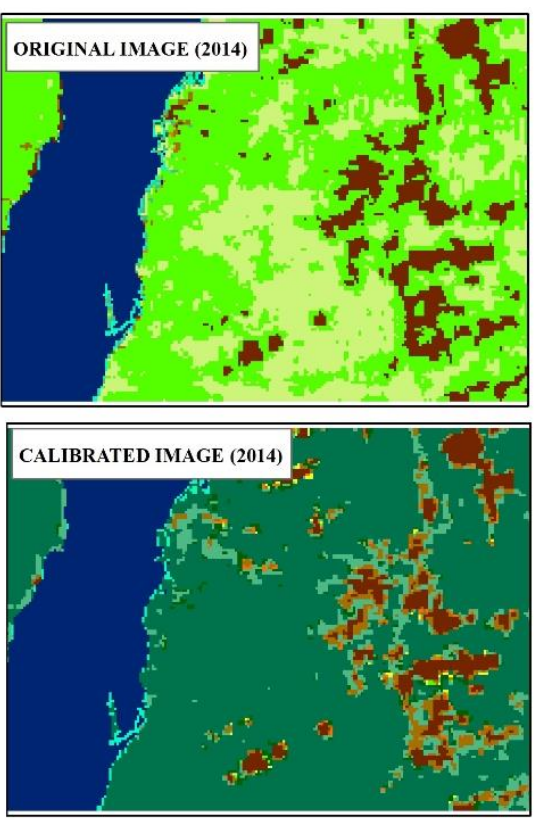

Figure 9 - MODIS classification results using the Maximum Likelihood Classifier. In which F= Forest, W=Water, $\mathrm{PA}=$ Pasture/Agriculture, and $\mathrm{BS}=$ Bare Soil.

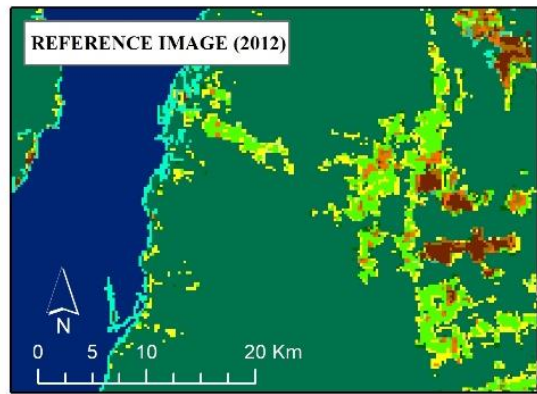

PROPORTION CLUSTERS:

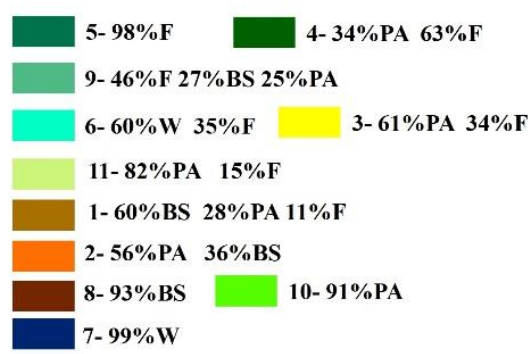

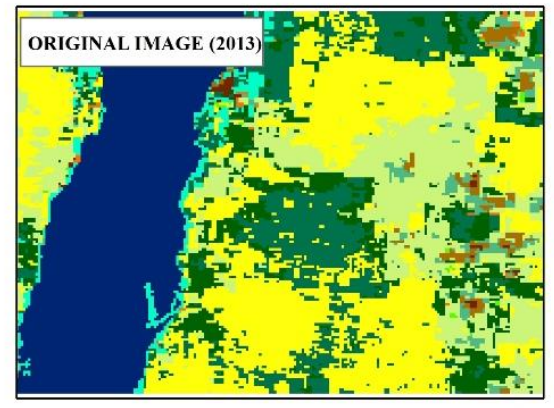

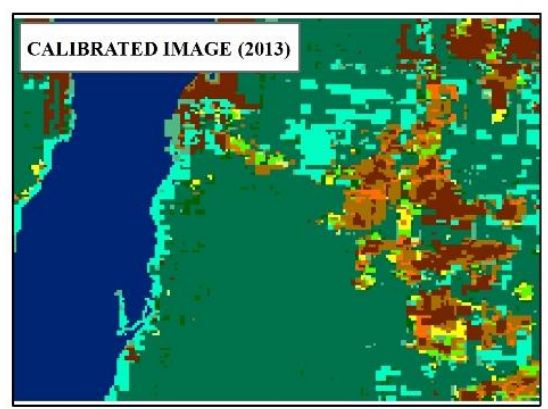

Source: The authors (2019).
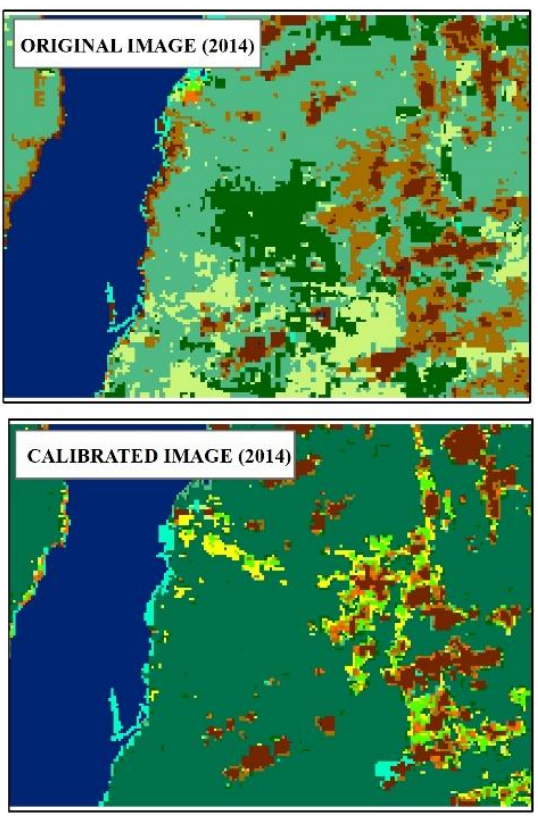

For the results of both classifiers, it is possible to notice that the calibration process greatly enhances the classification of Cluster 5, which represents areas predominantly occupied by Forest. When classifying the 
original images with training samples collected over the reference data, this class is misclassified to varied Clusters depending on the analyzed year and used classifier. This effect was further assessed by the comparison of the classified images to PRODES data. Note that Cluster 5 is correspondent to the class Forest in PRODES data. The concordance between the classifications of the years 2013 a 2017 and Forest class in PRODES data are presented in Chart 4. Please notice that correspondent classes are highlighted in bold font. In this chart, only results of the Maximum Likelihood classifier were presented.

Chart 4 - Ratios of agreement between the proportion cluster $5(98 \% \mathrm{~F})$ and Prodes Forest areas. In which $\mathrm{U}=$ Uncalibrated images, and $\mathrm{C}=$ Calibrated images.

\begin{tabular}{|c|c|c|c|c|c|c|c|c|c|c|}
\hline \multirow{2}{*}{ Class proportion } & \multicolumn{2}{|c|}{2013} & \multicolumn{2}{|c|}{2014} & \multicolumn{2}{|c|}{2015} & \multicolumn{2}{|c|}{2016} & \multicolumn{2}{|c|}{2017} \\
\hline & $\mathbf{U}$ & $\mathbf{C}$ & $\mathbf{U}$ & $\mathbf{C}$ & & $\mathbf{U}$ & $\mathbf{C}$ & & $\mathbf{U}$ & $\mathbf{C}$ \\
\hline $1-(60 \% \mathrm{BS}, 28 \% \mathrm{PA}, 11 \% \mathrm{~F})$ & 2 & 11 & 28 & 8 & 2 & 1 & 2 & 4 & 2 & 2 \\
\hline $2-(56 \% \mathrm{PA}, 36 \% \mathrm{BS})$ & 1 & 0 & 0 & 1 & 1 & 1 & 1 & 1 & 1 & 3 \\
\hline $3-(61 \% \mathrm{PA}, 34 \% \mathrm{~F})$ & 167 & 1 & 0 & 0 & 33 & 1 & 78 & 55 & 3 & 9 \\
\hline $4-(34 \% \mathrm{PA}, 63 \% \mathrm{~F})$ & 29 & 6 & 69 & 8 & 5 & 13 & 52 & 125 & 2 & 3 \\
\hline $5-(98 \% \mathrm{~F})$ & 66 & 229 & $\mathbf{0}$ & 286 & 260 & 284 & 86 & 91 & 304 & 296 \\
\hline $6-(60 \% \mathrm{~W}, 35 \% \mathrm{~F})$ & 7 & 48 & 2 & 4 & 6 & 2 & 17 & 15 & 2 & 2 \\
\hline $7-(99 \% W)$ & 0 & 0 & 1 & 0 & 0 & 0 & 0 & 0 & 0 & 0 \\
\hline $8-(93 \% \mathrm{BS})$ & 1 & 21 & 14 & 9 & 1 & 13 & 0 & 0 & 1 & 2 \\
\hline $9-(46 \% \mathrm{~F}, 27 \% \mathrm{BS}, 25 \% \mathrm{PA})$ & 1 & 3 & 173 & 1 & 2 & 2 & 12 & 1 & 2 & 1 \\
\hline $10-(91 \% \mathrm{PA})$ & 0 & 0 & 1 & 2 & 1 & 1 & 6 & 1 & 0 & 2 \\
\hline $11-(82 \% \mathrm{PA}, 15 \% \mathrm{~F})$ & 46 & 1 & 32 & 1 & 9 & 2 & 66 & 27 & 3 & 0 \\
\hline Total random points & 320 & 320 & 320 & 320 & 320 & 320 & 320 & 320 & 320 & 320 \\
\hline Of Agreement rate & $21 \%$ & $72 \%$ & $\mathbf{0}$ & $89 \%$ & $81 \%$ & $89 \%$ & $27 \%$ & $28 \%$ & $95 \%$ & $93 \%$ \\
\hline
\end{tabular}

As can be seen, the use of the relative calibration method improved the classification of the Forest $98 \%$ class for the majority of the analyzed images. This result was particularly expressive for years 2013 and 2014, in which the agreement rate improved from 21 to $72 \%$ and 0 to $89 \%$, respectively. For the remaining years, the difference in classification was less expressive, with a slight decrease in the agreement rate for the year 2017.

By the analysis of Chart 4, it is also possible to observe that the main misclassifications of Cluster 5 (98\% Forest) in original images varies depending on the analyzed date. In 2013, for example, this class is mainly misclassified as Clusters 3 (61\% Pasture/Agriculture, 34\% Forest) and 11(82\% PA, 15\% Forest). For 2014, this cluster was confused with Cluster 9 (46\% Forest, 27\% Bare Soil, 25\% Pature/Agriculture) and 4 (34\% Pasture/Agriculture, 63\% Forest).

The year 2016 is particularly interesting for this type of analysis, because of intrinsically differences in the characteristics of the forested areas. This year is marked by the existence of a large scale fire that changed the structure of forest class without changing the overall classification as forest. In this sense, we observe that although the agreement with PRODES data remained low (27 and $28 \%$ for uncalibrated and calibrated data, respectively), the use of calibrated images led to a more realistic classification: using calibrated images, these areas of degraded forests were classified almost evenly as any type of clustering that contained Forest and Pasture/Agriculture classes in any proportion whereas the classification of the calibrated images returned main clusters 4 and 5, which are dominated by forest classes. In this sense, this type of analysis may be useful to evaluated forest degradation, by the identification of a decrease in the forest percentage within classified clusters.

\section{CONCLUSIONS}

In the present study, we assessed the impacts of using relatively calibrated images for subpixel supervised classification of a MODIS time-series using generalized training data for one reference MODIS image. Image calibration was performed by the application of a simple linear regression model over average values of labeled samples of land cover classes. Overall, the calibration process was effective in decreasing the spectral differences between images of different dates in areas of correspondent land cover.

We showed that there may be great variance in the spectral response of same-class targets on the 
Earth's surface even in images of the same sensor and very proximate dates. Furthermore, these differences can greatly impact the performance of supervised classification when using transfer learning in subpixel analysis. As evidenced by the comparison of the classified maps and PRODES data, the supervised classification of Forest predominant classes was very poor when based on labeled samples of other images and uncalibrated MODIS data, with agreement rate as low as $0 \%$. However, these results were dramatically improved when using calibrated images, achieving agreement rates values higher than $70 \%$. These results confirm the importance of the calibration process for transferring the classification model among different dates in subpixels analysis using MODIS data in Amazon. The tools and methodology in this study are still in development. However, the analysis here presented indicate the need to test the calibration method using more types of land cover classes and in very small time intervals, and also with other configurations of MODIS data. Another perceived limitation is the inexistence of reference data for the analysis of all the proposed typologies which hindered the accuracy assessment of the complete map and further analysis of change in the area. Further steps include the development of tools and methods to properly measure the quality of this type of mapping, as well as how to properly perform change detection with this type of data. It is also interesting to further assess the potential of deforestation and forest degradation detection using the proposed methodology.

\section{Acknowledgments}

The authors are thankful to the Brazilian National Council for Scientific and Technological Development (CNPq), grants \#303360/2019-4, \#300127/2017-0, \#301049/2020-3 and \#309135/2015-0, and to the Coordination for the Improvement of Higher Education Personnel (CAPES).

\section{Author Contributions}

Conceptualization: L.V.D., T.S.K.; Data curation: N.A.P.M., M.S.R., E.F.C.; Formal analysis: N.A.P.M., M.S.R., E.F.C; Funding acquisition: T.S.K., L.V.D.; Investigation: N.A.P.M., M.S.R.; Methodology: T.S.K., L.V.D., E.A.; Project administration: T.S.K., L.V.D.; Resources: N.A.P.M., L.V.D.; T.S.K.; Software: E.F.C., M.S.R.; Supervision: L.V.D., T.S.K.; Validation: T.S.K., L.V.D., N.A.P.M., E.F.C., M.S.R., E.A.; Visualization: N.A.P.M., M.S.R.; Writing-original draft: N.A.P.M., M.S.R.; Writing - review \& editing: N.A.P.M., M.S.R.; T.S.K., L.V.D.; E.F.C., E.A.

\section{Conflicts Of Interest}

The authors declare no conflicts of interest.

\section{References}

ALMEIDA, C. A. DE.; COUTINHO, A. C.; ESQUERDO, J. C. D. M.; ADAMI, M.; VENTURIERI, A.; DINIZ, C. G.; DESSAY, N.; DURIEUX, L.; GOMES, A. R. High spatial resolution land use and land cover mapping of the Brazilian Legal Amazon in 2008 using Landsat-5/TM and MODIS data. Acta Amazonica, SciELO Brasil, v. 46, n. 3, p. 291-302, 2016. DOI. 10.1590/1809-4392201505504.

CÂMARA, G.; VINHAS, L.; FERREIRA, K.; QUEIROZ, G.; SOUZA, R.; MONTEIRO, A.; CARVALHO, M.; CASANOVA, M.; FREITAS, U. TerraLib: an open source GIS library for largescale environmental and socio-economic applications. In: Open Source Approaches in Spatial Data Handling 2 (Advances in Geographic Information Science), Springer, Berlin, Heidelberg, 2008. p. 247-270. DOI. 10.1007/9783-540-74831-1_12.

CASTEJON, E. SPAT - SubpixelAnalysis Tools. 2017. Available in: <http://www.dpi.inpe.br/ castejon /wiki/doku.php?id=wiki:software>. Accessed in: Oct. 2019.

CHANDER, G.; MEYER, D. J.; HELDER, D. L. Cross calibration of the Landsat-7 ETM+ and EO-1 ALI sensor. IEEE Transactions on Geoscience and Remote Sensing, v. 42, n. 12, p. 2821-2831, 2004. DOI: 
10.1109/TGRS.2004.836387.

CHHABRA, A.; GEIST, H.; HOUGHTON, R. A.; HABERL, H.; BRAIMOH, A. K.; VLEK, P. L. G.; PATZ, J.; XU, J.; RAMANKUTTY, N.; COOMES, O.; LAMBIN, E. F. Multiple impacts of land-use/cover change. In: LAMBIN, E.; GEIST, H. (Ed.). Land-use and Land-Cover Change. Global Change - The IGBP Series. Springer, Berlin, Heidelberg. p. 71-116, 2006. DOI. 10.1007/3-540-32202-7_4.

DEMIR, B.; BOVOLO, F.; BRUZZONE, L. Updating land-cover maps by classification of image time series: A novel change-detection-driven transfer learning approach. IEEE Transactions on Geoscience and Remote Sensing, v. 51, n. 1, p. 300-312, 2012. DOI. 10.1109/TGRS.2012.2195727.

DINIZ, C. G.; SOUZA, A. A. A.; SANTOS, D. C.; DIAS, M. C.; LUZ, N. C.; MORAES, D. R. V.; MAIA, J. S.; GOMES, A. R.; NARVAES, I. S.; VALERIANO, D. M.; MAURANO, L. E. P.; ADAMI, M. DETERB: the new Amazon near real-time deforestation detection system. IEEE Journal of Selected Topics in Applied Earth Observations and Remote Sensing, v. 8, n. 7, p. 3619-3628, July 2015. DOI. 10.1109/JSTARS.2015.2437075.

DU, Y.; TEILLET, P. M.; JOSEPH. C. Radiometric normalization of multitemporal high-resolution satellite images with quality control for land cover change detection. Remote Sensing of Environment. v. 82. p. 123-134, 2002. DOI. 10.1016/S0034-4257(02)00029-9.

Exelis Visual Information Solutions. Image Registration Tutorial. Boulder, Colorado: Exelis Visual Information Solutions. ITT Visual Information Solutions, 2009. Available in: < http://enviidl.com/help/Subsystems/envi/Content/Tutorials/Workflows/ImageRegTutorial.htm>. Accessed in: Jul. 2017.

FOLEY, J. A.; DEFRIES, R.; ASNER, G. P.; BARFORD, C.; BONAN, G.; CARPENTER, S. R.; CHAPIN, F. S.; COE, M. T.; DAILY, G. C.; GIBBS, H. K.; HELKOWSKI, J. H.; HOLLOWAY, T.; HOWARD, E. A.; KUCHARIK, C. J.; MONFREDA, C.; PATZ, J. A.; PRENTICE, I. C.; RAMANKUTTY, N.; SNYDER, P. K. Global consequences of land use. Science, v. 309, n. 5734, p. 570-574, 2005. DOI. 10.1126/science. 1111772 .

FOODY, G. M. Subpixel Methods in Remote Sensing. In: Jong S.M.D., Meer F.D.V. (eds) Remote Sensing Image Analysis: Including The Spatial Domain. Remote Sensing and Digital Image Processing, v. 5, Springer, Dordrecht, 2004. DOI. 10.1007/978-1-4020-2560-0_3.

HALL, F. G.; STREBEL, D. E.; NICKESON, J. E.; GOETZ, S.J. Radiometric rectification: toward a common radiometric response among multidate, multisensory images. Remote Sensing of Environment, v.35, n.1, p.11-27, 1991. DOI. 10.1016/0034-4257(91)90062-B.

HU,Y.; LIU, L.; JIAO, Q. Comparison of absolute and relative radiometric normalization use Landsat time series images, Proc. SPIE 8006, MIPPR 2011: Remote Sensing Image Processing, Geographic Information Systems, and Other Applications, v. 800616, 2011. DOI. 10.1117/12.902076.

INSTITUTO NACIONAL DE PESQUISAS ESPACIAIS (INPE). Monitoramento da floresta Amazônica brasileira por satellite. PRODES - Programa de Monitoramento da Floresta Amazônica Brasileira por Satélite, 2019. Available in: < http://www.obt.inpe.br/prodes/index.html>. Accessed in: Apr. 2019.

JUSTICE, C. O.; TOWNSHEND, J.R.G.; VERMOTE, E.F.; MASUOKA, E.; WOLFE, R.E.; SALEOUS, N.; ROY, D.P.; MORISETTE, J.T. "An overview of MODIS Land data processing and product status. Remote Sensing of Environment", v. 83, n.1-2, p. 3-15, 2002. DOI. 10.1016/S0034-4257(02)00084-6.

MOREIRA, N. A. P.; KÖRTING, T. S.; DUTRA, L. V.;CASTEJON, E. F.; ARAI, E. Calibração relativa para extensão de assinaturas em série de imagens MODIS. In: BRAZILIAN SYMPOSIUM ON GEOINFORMATICS (GEOINFO), XX, 2019, São José dos Campos, SP, Brazil. Proceedings... p. 230236. Available in: < http://urlib.net/rep/8JMKD3MGPDW34R/3UFEC9P>. Accessed in: Apr. 2019.

MOREIRA, N. A. P.; KÖRTING, T. S.; DUTRA, L. V.; CASTEJON, E.; ARAI, E. Metodologia para classificação subpixel de imagens MODIS com base em classificação de imagem de maior resolução. In: BRAZILIAN SYMPOSIUM ON GEOINFORMATICS (GEOINFO), XIX, 2018, Campina Grande, PB, Brazil. Proceedings... p. 146-151. Available in: <http://urlib.net/rep/8JMKD3MGPDW34P/3SG4E4P>. 
Accessed in: June 2019.

OLTHOF, I.; BUTSON, C.; FRASER, R. Signature extension through space for northern landcover classification: A comparison of radiometric correction methods. Remote Sensing of Environment, v. 95, n. 3, p. 290-302, 2005. DOI. 10.1016/j.rse.2004.12.015.

PAHLEVAN, N.; SCHOTT, J. R. Characterizing the relative calibration of Landsat-7 (ETM+) visible bands with Terra (MODIS) over clear waters: The implications for monitoring water resources. Remote Sensing of Environment, v. 125, p. 167-180, 2012. DOI. 10.1016/j.rse.2012.07.013.

PONZONI, F. J.; SHIMABUKURO, Y. E. Sensoriamento remoto no estudo da vegetação. São José dos Campos - SP: Editora Parêntese. 2007.

REIS, M. S.; ESCADA, M. I. S.; DUTRA, L. V.; SANT'ANNA, S. J. S.; VOGT, N. D. Towards a reproducible LULC hierarchical class legend for use in the southwest of Pará State, Brazil: a comparison with remote sensing data-driven hierarchies. Land, v. 7, n. 2, p. 65, 2018. DOI. 10.3390/land7020065.

ZHANG J.; FOODY G. M. A Fuzzy Classification of Sub-urban Land Cover from Remotely Sensed Imagery. International Journal of Remote Sensing. v. 19, n. 14, p. 2721-2738, 1998. DOI. 10.1080/014311698214479.

WOODCOCK, C. E.; MACOMBER, S. A.; PAX-LENNEY, M.; COHEN, W. B. Monitoring large areas for forest change using landsat: Generalization across space, time and landsat sensors. Remote Sensing of Environment, v. 78, n. 1-2, p. 194-203, 2001.

YANG, X. J.; LO, C.P. Relative Radiometric Normalization Performance for Change Detection from MultiDate Satellite Images. Photogrammetric Engineering \& Remote Sensing. v. 66, n. 8, p. 967-980, 1996. DOI. 10.1016/S0034-4257(01)00259-0.

YUAN, D.; ELVIDGE, C. D. Comparison of relative radiometric normalization techniques. Journal of Photogrammetry and Remote Sensing. v. 51, p. 117-126, 1996. DOI. 10.1016/0924-2716(96)00018-4.

\section{Lead author's biography}

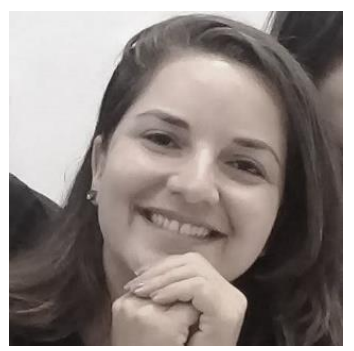

Noeli Aline Particcelli Moreira, Campinas-SP, 1985. N.A.P.M. holds a degree in Forestry Engineering and a Masters in Amazonian Forestry and Environmental Sciences, both from the Federal University of Amazonas - UFAM. She has experience in environmental monitoring and geotechnologies, with an emphasis on geoprocessing and remote sensing. She currently holds a research scholarship at the National Institute for Space Research, within the Earth Observation Center.

Esta obra está licenciada com uma Licença Creative Commons Atribuição 4.0 Internacional - CC BY. Esta licença permite que outros distribuam, remixem, adaptem e criem a partir do seu trabalho, mesmo para fins comerciais, desde que lhe atribuam o devido crédito pela criação original. 